Jurnal KIBASP (Kajian Bahasa, Sastra dan Pengajaran)

Volume 3, Nomor 1, Desember 2019

e-ISSN : 2597-5218

p-ISSN : 2597-520X

DOI : https://doi.org/10.31539/kibasp.v3i1.908

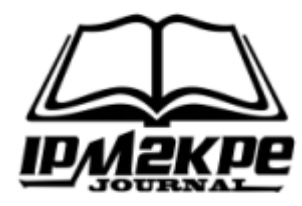

\title{
FUNGSI BAHASA DALAM ACARA BERASAN MASYARAKAT SINDANG KELINGI MUSI RAWAS
}

\author{
Cekman $^{1}$, Dedi $^{2}$ \\ SMA Negeri Karang Jaya ${ }^{1}$, STMIK Bina Nusantara Jaya Lubuklinggau ${ }^{2}$ \\ cekmane@yahoo.com ${ }^{1}$
}

Submit, 22-10-2019 Accepted, 28-12-2019 Publish, 28-12-2019

\begin{abstract}
ABSTRAK
Tujuan penelitian ini secara umum untuk mendeskripsikan fungsi bahasa berasan masyarakat Sindang Kelingi Musi Rawas. Data penelitian ini adalah tuturan (katakata/bahasa) yang terdapat dalam kegiatan berasan. Penelitian ini menggunakan data deskristif berupa kata-kata tertulis atau lisan dari orang-orang atau perilaku yang dapat diamati. Sumber data yang digunakan dalam penelitian ini adalah kegiatan berasan masyarakat. Penelitian ini menggunakan analisis data yang bersifat kualitatif. Simpulan, Fungsi bahasa berasan, terdapat lima fungsi, yaitu: 1) Fungsi personal (hanya menyatakan kegembiraan dan kesedihan), 2) Fungsi direktif (menyatakan permintaan dan rayuan), 3) Fungsi fatik (memperlihatkan perasaan persahabatan), 4) Fungsi metalingual (menjelaskan bahasa itu sendiri), 5) Fungsi imaginative (menyatakan perasaan bahwa pihak lelaki menghadap untuk menghatur kata dan rasa hormat).
\end{abstract}

Kata Kunci: Fungsi Bahasa, wacana, Acara Berasan

\section{ABSTRACT}

The purpose of this study in general is to describe the function of the rice language of the Sindang Kelingi Musi Rawas community. The data of this study are the utterances (words / languages) contained in rice activities. This study uses descriptive data in the form of written or oral words from people or observable behavior. The data source used in this research is community based activities. This research uses qualitative data analysis. Conclusion, The function of the language of rice, there are five functions, namely: 1) Personal function (only expressing joy and sadness), 2) Directive function (expressing requests and seduction), 3) Fatigue function (showing feelings of friendship), 4) Metalingual function ( explain the language itself), 5) Imaginative function (expressing the feeling that the male side faces to arrange words and respect).

Keywords: Language Function, Discourse, Rice Events

\section{PENDAHULUAN}

Setiap insan yang terlahir di muka bumi ini pasti bercita-cita ingin hidup bersama. Kebersamaan yang diwujudkan oleh pihak laki-laki dan perempuan itu biasanya terikat oleh pernikahan. Bagi masyarakat sindang kelingi, ada adat berasan 
yang harus dilakukan oleh kedua belah pihak sebelum menikah. Istilah berasan menurut bahasa Sindang Kelingi dapat diartikan secara luas sebagai berembug mengenai suatu urusan oleh kedua belah pihak untuk mendapatkan kesepakatan. Penelitian sebelumnya yang dilakukan oleh Ihsan, et.al (2017) mendeskripsikan mengenai adat minjam di Desa Guci kecamatan Ujan Mas Kabupaten Muara Enim, yang tradisi lamarannya harus melewati tiga fase yaitu fase acara lamaran yang dilakukan oleh pihak laki-laki melalui pemangku adat, fase meminjam calon mempelai perempuan untuk dibawa ke rumah mempelai lelaki selama 3-14 hari tanpa ditemani pihak keluarga, dan fase pengembalian calon mempelai perempuan ke rumah orang tuanya diiringi calon mempelai laki-laki sambil membawa lauk pauk yang akan dimakan secara bersama-sama.

Sedangkan penelitian yang dilakukan oleh Karim (2017) penyerahan hantaran adalah pertanda bahwa pihak laki-laki mengutus seseorang untuk bersilaturahmi ke rumah perempuan dan utusan ini akan mencari tahu apakah perempuan sudah dilamar orang atau belum, apabila belum maka pihak laki-laki akan mengikat perempuan dengan hantaran berupa sirih pinang dan cincin emas belah rotan. Iye (2018) berpendapat bahwa prosesi lamaran merupakan prosesi sacral yang dianggap masyarakat sebagai kewajiban dari suatu budaya. Lain halnya pendapat Mardhatillah (2014) pertunangan bagi dalam masyarakat Madura bukan hanya meresmikan perjodohan, melainkan sebagai jembatan menuju pernikahan tetapi juga sebagai bahasa bagi kedua calon mempelai untuk mengenal satu sama lain. Dalam arti yang lebih khusus, "berasan" sebagai pembicaraan kedua belah pihak untuk mendapatkan kesepakatan-kesepakatan yang berhubungan dengan proses menuju pernikahan seorang bujang dengan seorang gadis. Kegiatan dalam "berasan" untuk mencapai kesepakatan tersebut tidak terlepas dalam penggunaan bahasa Sindang Kelingi sebagai sarana interaksi dan komunikasi antara kedua belah pihak (Dedi \& Cekman, 2018)

Ngulang rasan atau berasan merupakan kunjungan pertama orang tua pihak lelaki ke rumah pihak perempuan untuk melanjutkan rasanan pihak lelaki terhadap perempuan. Sebelum pihak lelaki datang ke rumah keluarga pihak perempuan, terlebih dahulu sang perempuan akan memberitahukan kepada orang tuanya bahwa mereka akan kedatangan tamu. Dalam acara ngulang rasan/ berasan ini pihak lelaki membawa bolu, kue-kue, uang dua kali lipat dari uang basindo/merasan, dan sirih. Pemberian berbagai macam ini dinamakan dengan narok gan. Saat ngulang rasan orang tua lelaki akan 
menanyakan kepada orang tua perempuan, apakah benar anaknya telah memberikan GAN/tanda sewaktu pacaran. Orang tua perempuan menanyakan langsung kepada anak gadisnya tentang kebenaran hal tersebut. Jika terjadi kata sepakat antara keduanya mengenai ngulang rasan ini, maka akan dilanjutkan dengan pertemuan-pertemuan selanjutnya untuk memantapkan hubungan bujang dan dehe kearah yang lebih serius dalam menjalin suatu ikatan yaitu membangun rumah tangga. (Dedi, 2014)

Tahapan sebelum perkawinan dalam masyarakat Sindang Kelingi ada lima, yaitu, 1) pergaulan muda-mudi, 2) ngulang rasan, 3) tiang kule, 4) ngantat dendan, dan 5) belabu keje (Darwis \& Prijaya, 2010). Seiring dengan perkembangan zaman, banyak terjadi perubahan pada aspek budaya khususnya upacara perkawinan adat Sindang Kelingi. Perubahan-perubahan yang terjadi bukan hanya sekedar penyederhanaan yang disebabkan pertimbangan waktu, tenaga dan biaya, akan tetapi penghilangan atau peniadaan tahapan sebelum perkawinan khususnya tahap kedua yaitu ngulang rasan/berasan.

Bahasa merupakan alat komunikasi yang penting bagi manusia sehingga dalam kenyataannya bahasa menjadi aspek penting dalam melakukan sosialisasi atau berinteraksi sosial. Bahasa meliputi tataran fonologi, morfologi, sintaksis, semantik, dan wacana. Berdasarkan hierarkinya, wacana merupakan wacana tataran bahasa yang terbesar, tertinggi, dan terlengkap.

Dalam masyarakat Indonesia, kata bahasa sering dipergunakan dalam berbagai konteks dan berbagai makna. Ada yang berbicara tentang bahasa warna, bahasa bunga, bahasa komputer, bahasa diplomasi, bahasa militer, bahasa politik, dan sebagainya. Di samping itu dalam kalangan terbatas, terutama dalam kalangan orang yang mendalami seluk beluk bahasa, ada sejumlah sebutan bahasa, seperti bahasa lisan, bahasa tulisan, dan bahasa tutur.

Chaer \& Agustina (2004) membagi fungsi bahasa yaitu, (a) dari sudut penutur berfungsi personal maksudnya si penutur menyatakan sikap terhadap apa yang dituturkanya. Si penutur bukan hanya mengungkapkan emosi lewat bahasa, tetapi juga memperlihatkan emosi itu sewaktu menyampaikan tuturannya. Dalam ini pihak si pendengar juga dapat menduga apakah si penutur sedih, marah, atau gembira, (b) dari segi pendengar fungsinya direktif yaitu mengatur tingkah laku pendengar. Di sini bahasa itu tidak hanya membuat si pendengar melakukan sesuatu, tetapi melakukan 
kegiatan yang sesuai dengan yang dimaui si pembicara. Hal ini dapat dilakukan si penutur dengan menggunakan kalimat-kalimat yang menyatakan perintah, himbauan, permintaan, maupun rayuan, (c) dari segi penutur dan pendengar maka bahasa berfungsi fatik yaitu fungsi menjalin hubungan, memelihara, memperlihatkan perasaan bersahabat, atau solidaritas sosial. Ungkapan-ungkapan yang digunakan biasanya sudah berpola tetap, seperti pada waktu berjumpa, pamit, membicarakan cuaca, atau menanyakan keadaan keluarga.

Ungkapan-ungkapan fatik ini biasanya juga disertai dengan unsur paralinguistic, seperti senyuman, gelengan kepala, gerak-gerik tangan, air muka, dan kedipan mata. Ungkapan-ungkapan tersebut yang disertai unsure paralinguistik tidak mempunyai arti, dalam arti memberikan informasi, tetapi membangun kontak sosial antara partisipan didalam pertuturan ini, (d) dari segi topik ujaran fungsi bahasa sebagai referensial yaitu bahasa berfungsi sebagai alat untuk membicarakan objek atau peristiwa yang ada disekeliling penutur atau yang ada dalam budaya pada umumnya. Fungsi referensial inilah yang melahirkan paham tradisional bahwa bahasa itu adalah alat menyatakan pikiran untuk menyatakan bagaimana pendapat si penutur tentang dunia di sekelilingnya, (e) dari segi kode bahasa berfungsi metalingual, yakni bahasa digunakan untuk membicarakan bahasa itu sendiri. Biasanya bahasa itu digunakan untuk membicarakan masalah lain, tetapi dalam fungsinya di sini bahasa itu digunakan untuk membicarakan atau menjelaskan bahasa. Hal ini dapat dilihat dalam proses pembelajaran bahasa di mana kaidah-kaidah atau aturan-aturan bahasa dijelaskan dengan bahasa. Juga dalam kamus monolingual, bahasa itu digunakan untuk menjelaskan arti bahasa (dalam hal ini kata) itu sendiri, (f) dari segi amanat, bahasa berfungsi imaginatif biasanya berupa karya seni yang digunakan untuk kesenangan penutur maupun para pendengarnya. Sesungguhnya bahasa itu dapat digunakan untuk menyampaikan pikiran, gagasan, dan perasaan, baik yang sebenarnya, maupun yang cuma imaginasi (khayal, rekaan) saja.

Adapun fungsi bahasa yang dipergunakan dalam penelitian ini adalah acara berasan masyarakat Sindang Kelingi Kabupaten Musi Rawas. Penelitian tentang acara berasan masyarakat Sindang Kelingi Kabupaten Musi Rawas telah dilakukan oleh Dedi \& Cekman (2018) adalah analisis wacana dari perangkat kohesi leksikal dalam acara berasan masyarakat Sindang Kelingi Kabupaten Musi Rawas mencakup repetisi 
(pengulangan), sinonimi (padan kata), kolokasi (sanding kata), hiponimi (hubungan atas-bawah), antonimi (lawan kata, oposisi makna), dan ekuivalensi (kesepadanan bentuk). Penelitian tentang bahasa Sindang telah dilakukan oleh Noermanzah (2017) fokus pada kalimat tunggal Bahasa Sindang Lubuklinggau yang berpredikat verbal yang teridiri atas kalimat intransitif dan kalimat ekatransitif, kalimat tunggal berpredikat adjektival, kalimat tunggal predikat nominal, kalimat tunggal predikat numeral, kalimat tunggal berpredikat preposisional, dan kalimat tunggal adverbial.

Namun penelitian ini mengkaji tentang fungsi bahasa berasan masyarakat Sindang Kelingi Musi Rawas agar nantinya mampu menjadi data dan bahan pengembangan dalam wacana lisan acara berasan. Selain itu, dapat memberikan informasi tentang makna yang sebenarnya acara lamaran Berasan pada masyarakat Sindang Kelingi Kabupaten Musi Rawas dibangun oleh unsur fungsi bahasa.

\section{METODE PENELITIAN}

Metode yang digunakan dalam penelitian ini adalah pendekatan kualitatif dengan metode deskriptif. Data penelitian ini adalah tuturan (kata-kata/bahasa) yang terdapat dalam kegiatan berasan/ngulang rasan. Sumber data yang digunakan dalam penelitian ini adalah kegiatan ngulang rasan masyarakat Sindang Kelingi Kabupaten Musi Rawas.

Teknik pengumpulan data merupakan suatu cara yang digunakan untuk memperoleh atau mengumpulkan data yang dibutuhkan dalam penelitian. Untuk memperoleh data yang sesuai dengan permasalahan diperlukan teknik pengumpulan data. Teknik pengumpulan data yang digunakan dalam penelitian ini yaitu Observasi dan wawancara. Observasi bertujuan untuk memudahkan peneliti untuk memahami konteks data, situasi sosial, dan pengalaman langsung.

Instrumen penelitian ini menggunakan panduan/kisi analisis wacana. Dalam kisi analisis berdasarkan kisi analisis wacana yaitu: 1) fungsi personal, 2) fungsi direktif, 3) fungsi fatik, 4) fungsi referensial, 5) fungsi metalingual, dan 6) fungsi imaginatif. Analisis ini mendeskripsikan mengenai analisis wacana dari fungsi bahasa berasan. Proses analisis ini difokuskan terhadap wacana bahasa berasan berdasarkan dari wacana awal, wacana isi dan wacana penutup.

Tahapan analisis penelitian ini sebagai berikut, pertama, transkrip wacana bahasa berasan Sindang Kelingi dibaca dan dipahami dalam rangka mendapatkan 
pemahaman kasar tentang kegiatan penelitian yang telah dilaksanakan. Kedua, seluruh wacana bahasa berasan yang sudah dibaca dan dipahami untuk mengetahui bagian awal wacana, isi wacana penutup wacana bahasa berasan Sindang Kelingi dari fungsi bahasa. Ketiga, analisis difokuskan pada fungsi bahasa dari wacana bahasa berasan Sindang Kelingi. Keempat, analisis difokuskan pada fungsi bahasa berasan Sindang Kelingi Musi Rawas. Kelima, analisis wacana bahasa berasan Sindang Kelingi diakhiri dengan menemukan fungsi bahasa berasan.

\section{HASIL PENELITIAN}

Prosesi adat masyarakat sindang kelingi ada dua tahapan yaitu tahapan sebelum perkawinan dan tahapan adat perkawinan. Tahapan sebelum perkawinan yaitu, 1) pergaulan muda-mudi, 2) ngulang rasan, 3) tiang kule, 4) ngantat dendan, 5) belabu keje, sedangkan tahapan adat perkawinan adalah 1) nikah, 2) tan agung (hari memasak), 3) pesta malam (Deker), 4) mapak sedekah (resepsi), 5) mandi kasai.

Dalam wacana bahasa berasan Masyarakat Sindang Kelingi setelah dilakukan penelitian dan dianalisis ditemukan tidak mempunyai ekuivalensi (kesepadanan bentuk). Artinya pada kondisi tertentu, unsur-unsur kohesi menjadi kontributor penting bagi terbentuknya wacana yang koheren. Namun demikian perlu disadari bahwa unsur-unsur kohesi tersebut tidak selalu menjamin terbentuknya wacana yang utuh dan koheren. Alasannya, pemakaian alat-alat kohesif dalam suatu teks tidak langsung menghasilkan wacana yang koheren. Berdasarkan hasil temuan, wacana bahasa berasan masyarakat Sindang kelingi Musi Wacana bahasa berasan masyarakat Sindang Kelingi ditemukan tidak mempunyai fungsi bahasa sebagai referensial yaitu bahasa berfungsi sebagai alat untuk membicarakan objek atau peristiwa yang ada disekeliling penutur atau yang ada dalam budaya pada umumnya.

Fungsi referensial inilah yang melahirkan paham tradisional bahwa bahasa itu adalah alat menyatakan pikiran untuk menyatakan bagaimana pendapat si penutur tentang dunia di sekelilingnya. Artinya dalam wacana bahasa berasan Sindang Kelingi hanya terdapat lima fungsi bahasa yaitu, 1) fungsi personal, 2) fungsi direktif, 3) fungsi fatik, 4) fungsi metalingual, 5) fungsi imaginatif. Kelima fungsi bahasa tersebut akan diuraikan satu persatu sebagai berikut: 


\section{Fungsi Personal}

Dilihat dari segi sudut penutur, maka bahasa itu berfungsi personal atau pribadi. Fungsi personal dalam bahasa kegiatan berasan masyarakat sindang kelingi, dimana Ketua Berasan Bujang (KRB) menyatakan rasa gembira bahwa mereka datang dengan membawa bujang yang tampanpernyataan ini terlihat dalam kutipan dibawah ini.

Ayolah besan makan sirih, sirih kalakap pinang talang, sirih dak cukup pinang kurang, kak lah oleh Bujang Alap”. (KRBA 1)

Pada kalimat berikutnya dimana Ketua Berasan Dehe (KRDI 3) Menyatakan kesedihan bahwa gadis karena yang mau dipinang pemuda tersebut hidupnya tidak terurus, saudaranya banyak, gadis miskin yang banyak keinginan, pernyataan ini terlihat dalam kutipan dibawah ini.

Yang manè dehè kak idup tekepèr debedèk banyak, awak besat banyak

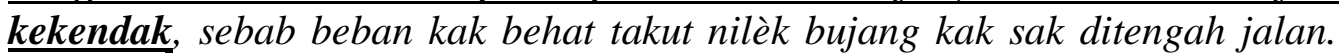
(KRDI 3)

\section{Fungsi Direktif}

Fungsi direktif dalam bahasa kegiatan berasan masyarakat Sidang Kelingi yang menyatakan

(1) permintaan pihak rasan bujang kepada pihak rasan perempuan untuk makan sirih yang merupakan oleh-oleh bujang yang tampan.

Ayolah besan makan sirih, sirih kalakap pinang talang, sirih dak cukup pinang kurang, kak lah oleh Bujang Alap”. (KRBA 1)

(2) permintaan pihak rasan bujang kepada pihak rasan gadis bahwa pemuda akan meminang gadis tersebut

Kami kak adè semajè, menurut kabar dari sang Bujang kami, di uma kak adè Dèhè, kabar a Bujang ngan Dehè kak la bebusik, begurau ngan Dehè ulasa la lamè bebusik adè katè sepakat, Bujang kami nak minang Dehè hikak”. (KRBA 2)

(3) menyatakan rayuan yang disampaikan pihak rasan bujang bahwa pemuda mengatakan kesanggupan segala sesuatu hal baik yang kecil maupun yang besar dan menerima gadis tersebut apa adanya dan tidak menyesal sampai mati

Yè cam kak, yang manè bujang la ngatè atak kami brèkat segalè titik tampung

kami hanggup, bujang dak sak tengah jalan dan pulè iyè dak ngecas naèk tebing dan dak pulè ngicing nyebrang ayo. (KRBI 3) 
(4) menyatakan permintaan yang disampaikan pihak rasan gadis bahwa pihak pemuda harus memenuhi permintaan dari gadis berupa uang, beras, ayam, kelapa dll, jika ingin melangsunkan pernikahan.

Jadi perjanjian tuh, hatu di ako anak due pintaan (Sen, behas, ayam, niyo dll) ketigè mas kawin, kalu nga hanggup pintaan tuh, rasan kak jadi, kalu dak hanggup dak yu kite jadi a. (KRDI 4)

(5) Permintaan kepada pihak rasan gadis bahwa pemuda akan melakukan sembah sujud kepada pihak keluarga gadis.

Kedatangan kami, bak rèbèsè tuh, kapak hekali lukè duè, kami nak nyerah hembah hujud, supayo yè kak tau keluarge dehe tu, mane metuè, ipo tuè, nenek, wak, bibi, mamang dan yang lain-lain a. (KRBP 5)

(6) Pernyataan yang menyatakan permintaan kepada pihak pemerintah setempat untuk memberikan arahan agar nantinya pernikahan ini berjalan baik, terdapat dalam kutipan di bawah ini.

kalu kelam mintèk diterang, kalu kusut mintèk dilesai, kalu condong mintèk ditegakkan. (KRBP 6)

\section{Fungsi Fatik}

Fungsi fatik yang terdapat dalam bahasa berasan masyarakat Sindang Kelingi Musi Rawas yang memperlihat perasaan persahabatan bahwa pihak rasan bujang menyatakan apapun keinginan dari pihak rasan bujang siap untuk menerimanya, terdapat dalam kutipan di bawah ini.

Ayolah calon bèsan, namè semajè ponga, kami siap tuk nerimè̀". (KRDA 1)

\section{Fungsi Metalingual}

Dalam bahasa kegiatan berasan ini, ada bahasa yang digunakan untuk menjelaskan arti bahasa dalam kegiatan berasan itu sendiri yang disampaikan oleh Pihak Rasan Bujang. Hal ini terdapat dalam kutipan dibawah ini.

Kedatangan kami, bak rèbèsè tuh, kapak hekali lukè duè , kami nak nyerah hembah hujud, (KRBP 5)

\section{Fungsi Imaginatif}

Dalam kegiatan berasan ini bahasa dapat digunakan untuk menyampaikan pikiran, gagasan, dan perasaan, baik yang sebenarnya maupun yang cuma imaginasi 
(khayalan, rekaan). Adapun fungsi imaginatif bahasa kegiatan berasan Masyarakat Sindang kelingi terdapat dalam kutipan sebagai berikut.

(1) Menyatakan perasaan KRB kepada KRD bahwa pihak lelaki menghadap untuk mengatur kata dan rasa hormat .

Atak ayak si atak ayak, atak ayak lorè temègè, sirih pinang ku atur dulu, atak ayak ku ngatur katè, sembah ku ngiring mangunian. (KRBA 1)

(2) Menyampaikan pikiran kepada pihak lelaki untuk memikirkan dulu pinangan ini, takutnya nanti menyesal sebelum hal ini dilaksanakan.

Sebekal idak di ulu, sebekal ditepian tullah, nyesal idak dulu nyesal datang kemudian tullah. Jadi GAN kami balèk kudai, supayo bujang bepikir atau betimbang abis-abis' (KRDI 3)

(3) Menyatakan gagasan bahwa tanda (GAN) tidak dibawah pulang malah akan ditambah.

Kapung mang kapung serè, kapung jelatang lebat buah, kami dak ngundè gan balèk, kami datang hakikat kami nak nambah. (Kemudian GAN dikembalikan lagi kepada Ketua Rasan Dehe). (KRBI 3)

(4) Menyatakan gagasan bahwa pemuda tersebut sekalian melakukan salaman/sembah sujud dengan keluarga gadis.

Kedatangan kami, bak rèbèsè tuh, kapak hekali lukè duè, kami nak nyerah hembah hujud, supayo yè kak tau keluarge dehe tuh, mane metuè, ipo tuè, nenek, wak, bibi, mamang dan yang lain-lain a. (KRBP 5)

\section{PEMBAHASAN}

Bahasa dalam kegiatan berasan mempunyai maksud dan tujuan tersendiri dalam menyampaikan keinginan oleh kedua belah pihak. Berdasarkan pendapat Karim (2017) dalam mengekpresikan petata-petiti (kata-kata kias, pantun, dan penyelo) setiap orang diberikan kebebasan tetapi biasanya tetap berpedoman pada ketentuan-ketentuan yang berlaku. Sedangkan Trisnawati, (2018) sebagai mahluk sosial yang berinteraksi menggunakan bahasa dalam kegiatan berinteraksi, pilihan kata (ucapan) harus sesuai dengan kaidah yang berlaku. Agustina (2016) kebudayaan yang memiliki nilai dan adat istiadat dalam kegiatan berbicara biasanya terikat oleh aturan tertentu dalam suatu daerah. Sedangkan Husmiwati (2015) tradisi lisan pada saat penyelenggaraan upacara adat memiliki bahasa yang teratur dan berirama, serta mempunyai tanda yang bertujuan untuk menyatakan maksud, rasa hormat, dan tanda kebesaran. 
Dalam kegiatan berasan bahasa yang digunakan lebih menonjolkan petatapetiti dalam menyampaikan lamaran tersebut. Dari hasil penelitian ditemukan beberapa fungsi bahasa dalam bahasa kegiatan berasan masyarakat Sindang Kelingi Musi Rawas harus memahami makna setiap kalimat menggunakan bahasa kias, peribahasa, pepatah, dan pantun yang disampaikan oleh masing-masing ketua rasan. Pertama ditemukan kata kias pada kutipan atak ayak ku ngatur katè, sembah ku ngiring mangunian. Kata kiasan yang digunakan dalam bahasa berasan masyarakat Sindang Kelingi Musi Rawas dalam melakukan sosialisasi antar masyarakat dan menghormati orang-orang yang merupakan bagian dari keluarga seorang gadis. Kedua ditemukan peribahasa pada kata kapak hekali lukè duè, kalu kelam mintèk diterang, kalu kusut mintèk dilesai, kalu condong mintèk ditegakkan. Peribahasa yang digunakan bermaksud untuk menyampaikan maksud pihak bujang kepada pihak gadis. Ketiga ditemukan pepatah pada awak besat banyak kekendak yang menggunakan majas perbandingan.

\section{SIMPULAN}

Fungsi bahasa Berasan masyarakat Sindang Kelingi Musi Rawas, terdapat lima fungsi bahasa. Adapun fungsi bahasa berasan tersebut yaitu: 1) fungsi personal (hanya menyatakan kegembiraan dan kesedihan), b) fungsi direktif (menyatakan permintaan dan rayuan), c) fungsi fatik (memperlihatkan perasaan persahabatan), d) fungsi metalingual (menjelaskan bahasa itu sendiri), e) fungsi imaginative (menyatakan perasaan bahwa pihak lelaki menghadap untuk mengatur kata dan rasa hormat). Fungsifungsi bahasa berasan tersebut baiasanya terdapat pada bahasa kias, peribahasa, dan pantun.

\section{DAFTAR PUSTAKA}

Agustina, R., \& Amelia, D. (2016). Analisis Struktur Fisik dalam Pantun dan Budaya Adat Istiadat Tata Cara Perkawinan Kabupaten Sambas Karya Hamdan Simad dan Muhanni Abdur. Jurnal Lingua, 12(1)

Chaer, A., \& Leonie, A. (2004). Sosilinguistik Perkenalan Awal. Bandung: PT. Rineka Cipta

Darwis \& Sabda, P. (2010). Tata Cara Adat Perkawinan Sukubangsa Linggau di Sumatera Selatan. Dinas Pendidikan Sumatera Selatan.

Dedi. (2014). Analisis Wacana Bahasa Berasan Masyarakat Sindang Kelingi Musi Rawas. Skripsi, Fakultas Keguruan dan Ilmu Pendidikan Universitas Bengkulu. 
Dedi \& Cekman. (2018). Kohesi Leksikal Dalam Acara Berasan Masyarakat Sindang Kelingi Musi Rawas. Silampari Bisa, Jurnal Penelitian Pendidikan Bahasa Indonesia, Daerah, dan Asing, 1(1)

Husmiwati, K. (2015). Pemolaan Komunikasi Tradisi Basiacuang sebagai Bentuk Kearifan Lokal dalam Upacara Pernikahan Masyarakat Melayu Kampar Provinsi Riau (studi Etnografi Komunikasi Tradisi Basiacuang di Desa Kuok Kecamatan Kouk Kabupaten Kampar). Jom FISIF, 2(1)

Ihsan, (2017). Minjam Adat Melamar di Desa Guci Kec. Ujan Mas Kab. Muara Enim Sumatera Selatan. JSA 1(1)

Iye, R. (2018). Tuturan dalam Prosesi Lamaran Pernikahan di Tomia Kabupaten Wakatobi. Jurnal Totobuang, 6(2)

Karim, M. (2017). Jurnal Fungsi Bahasa dalam Selako Adat Perkawinan Masyarakat DesaTantan Kecamatan Sekernan Kabupaten Muaro Jambi. http://repository.unja.ac.id/id/id/eprint2210. 13 Oktober 2017

Mardhatillah \& Masyithah. (2014). Perempuan Madura sebagai Simbol Prestise dan Pelaku Tradisi Perjodohan. Musawa, 13(2)

Noermanzah, N. (2017). Struktur Kalimat Tunggal Bahasa Sindang di Kota Lubuklinggau dan Pengaruhnya dalam Pembelajaran Bahasa Indonesia. AKSIS: Jurnal Pendidikan Bahasa dan Sastra Indonesia, 1(2)

Trisnawati, D, (2018). Medan Makna Peristilahan Prosesi Adat Perkawinan Masyarakat Jawa di Rasau Jaya. Jurnal Pendidikan dan Pembelajaran Khatulistiwa. 7(2) 